\title{
ANALISIS POLA KOMUNIKASI ANTARBUDAYA PARA SANTRI DI PONDOK PESANTREN TAHFIDZ DAARUL QURAN JAWA TENGAH
}

\author{
Atrianing Yessi Wijayanti, Nimas Puspitasari \\ Fakultas Keguruan dan Ilmu Pendidikan UNDARIS, atrianingyessiw@gmail.com
}

\begin{abstract}
ABSTRAK
Pondok Pesantren Tahfidz Daarul Qur'an Jawa Tengah merupakan salah satu lembaga tahfidz qur'an terbaik se-Indonesia. Pondok pesantren ini memiliki santri yang datang dari berbagai daerah antara lain pulau Jawa, Sumatera, Kalimantan, Maluku, Sulawesi, dan Madura. Kesulitan dalam berkomunikasi karena latar belakang kebudayaan, suku dan bahasa yang berbeda menjadikan pondok pesantren tersebut sebagai daerah multietnis di dalamnya. Tujuan Penelitian ini adalah untuk menganalisis pola komunikasi dan mengetahui faktorfaktor pendukung dan penghambat pola komunikasi antarbudaya Para Santri di Pondok Pesantren Tahfidz Daarul Quran Jawa Tengah. Penelitian ini menggunakan metode deskriptif dengan menggunakan pendekatan kualitatif. Penelitian ini dilaksanakan di Pondok Pesantren Tahfidz Daarul Qur'an Jawa Tengah beralamat di Dusun Suruhan, Desa Keji, Kecamatan Ungaran Barat, Kabupaten Semarang, Jawa Tengah, Indonesia. Penelitian ini dilaksanakan pada bulan Maret 2018. Tahap-tahap dalam penelitian ini antara lain: (1) mengidentifikasi dan merumuskan masalah, (2) pengumpulan data, dan (3) analisis dan penyajian data. Sumber data penelitian diambil dari sumber data primer dan sumber data sekunder. Teknik pengumpulan data penelitian ini dengan metode observasi, metode wawancara dan dokumentasi. Analisis data penelitian ini menggunakan pengumpulan data, reduksi data, penyajian data dan penarikan kesimpulan. Berdasarkan hasil observasi dan wawancara dengan informan pola komunikasi antarbudaya para santri di Pondok Pesantren Tahfidz Darul Quran Jawa Tengah meliputi pola komunikasi simbolik dan langsung. Pola komunikasi simbolik terdiri atas pola komunikasi verbal berupa bahasa yang digunakan para santri di lingkungan pondok pesantren serta pola komunikasi nonverbal berupa perilaku maupun ekspresi saat berinteraksi dengan teman santri, hal itu terjadi secara langsung sehingga akan menimbulkan umpan balik (feedback) dari komunikator kepada komunikan. Faktor pendukung yang terdapat pada proses komunikasi antarbudaya yang dilakukan oleh para santri adanya ketertarikan saat berkomunikasi, kemampuan berkomunikasi, sikap saling percaya, sikap ramah dan sopan santun, kemampuan beradaptasi, kejelasan informasi, bahasa dan lambang. Sedangkan faktor penghambat komunikasi anntarbudaya ini adalah watak individu, persepsi pelaku komunikasi, pengaruh budaya lain, dan perbedaan bahasa.
\end{abstract}

Kata kunci: Pola Komunikasi, Antarbudaya. 


\section{PENDAHULUAN}

Salah satu pondok pesantren baru di Kabupaten Semarang adalah Pondok Pesantren Tahfidz Daarul Qur'an yang dikenal secara luas oleh masyarakat sebagai salah satu lembaga tahfidz qur'an terbaik se-Indonesia. Pondok Pesantren Daarul Qur'an adalah pondok pesantren yang berbasis Qur'ani yang merupakan cabang dari pondok Daarul Qur'an milik Ustadz Yusuf Mansur yang berada di Jawa Barat. Pondok Pesantren Tahfidz Daarul Qur'an Jawa Tengah dibangun tahun 2014 berlamat di Dusun Suruhan, Desa Keji, Kecamatan Ungaran Barat, Kabupaten Semarang, Jawa Tengah, Indonesia. Pondok Pesantren Daarul Qur'an di Ungaran Barat dikhususkan bagi anak laki-laki tingkat SMP. Berdasarkan hasil observasi dan wawancara dengan pengelola dan guru pada tanggal 25 Mei 2017, Pondok Pesantren Tahfidz Daarul Qur'an di Ungaran Barat memiliki banyak santri yang datang dari berbagai daerah dari sabang sampai merauke, antara lain dari dari pulau Jawa, Sumatera, Kalimantan, Maluku, Sulawesi bahkan Papua Hal tersebut tentulah menimbulkan banyak kendala dan kesulitan dalam berkomunikasi karena latar belakang budaya, suku dan bahasa yang berbeda. Berdasarkan realita yang terjadi secara tidak langsung menjadikan Pondok pesantren Tahfidz Daarul Quran sebagai daerah multietnis di dalamnya. Banyaknya pendatang dari berbagai daerah dan memiliki berbagai tujuan, tentunya hal ini dapat menjadi bukti bahwa Pondok pesantren Tahfidz Daarul Quran merupakan

pondok pesantren yang menarik dan istimewa. Berdasarkan latar belakang masalah di atas maka penulis merasa perlu mengkaji lebih dalam penelitian yang berjudul: “Analisis Pola Komunikasi Antarbudaya Para Santri di Pondok Pesantren Tahfidz Daarul Quran Jawa Tengah”.

Tujuan penelitian ini adalah untuk menganalisis pola komunikasi serta mengetahui faktor-faktor penghambat dan pendukung pola komunikasi antar 
budaya para santri di Pondok Pesantren Tahfidz Daarul Quran Jawa Tengah.

\section{Kajian Pustaka}

Menurut Effendy (2014: 6) komunikasi adalah proses penyampaian suatu pesan oleh seseorang kepada orang lain untuk memberitahu atau untuk mengubah sikap, pendapat atau perilaku, baik langsung secara lisan, maupun tak langsung melalui media. Selanjutnya Effendy menjelaskan bahwa pola komunikasi merupakan suatu proses penyampaian pikiran oleh komunikator kepada komunikan dengan menggunakan suatu lambang sebagai media atau saluran. Dalam pola ini terbagi menjadi dua lambang yaitu lambang verbal dan lambang nonverbal.

Selanjutnya Mulyana (2005: 20) menjelaskan bahwa komunikasi antarbudaya merupakan sebuah situasi yang terjadi bila pengirim pesan adalah anggota suatu budaya dan penerima pesannya adalah anggota dari suatu budaya yang lain. Dalam keadaan demikian komunikan atau komunikator dihadapkan kepada maasalah-masalah yang ada dalam suatu siatuasi dimana suatu pesan disandi dalam suatu budaya dan harus disandi balik dalam budaya lain.

\section{Metode}

Penelitian ini menggunakan metode deskriptif dengan menggunakan pendekatan kualitatif. Menurut Moleong (2011: 19) metode deskripsi juga dapat diartikan sebagai prosedur pemecahan masalah yang diselidiki dengan menggambarkan atau melukiskan keadaan subjek atau objek peneliti pada saat sekarang berdasarkan fakta- fakta yang tampak atau sebagai mestinya.

Lokasi penelitian ini di Pondok Pesantren Tahfidz Daarul Qur'an Jawa Tengah beralamat di Dusun Suruhan, Desa Keji, Kecamatan Ungaran Barat, Kabupaten Semarang, Jawa Tengah, Indonesia. Penelitian ini dilaksanakan pada bulan Maret tahun 2018. Tahap-tahap dalam penelitian ini antara lain: (1) mengidentifikasi dan merumuskan masalah dengan melakukan observasi awal ke 
pondok pesantren, (2) pengumpulan data, dan (3) analisis dan penyajian data.

Sumber data penelitian diambil dari sumber data primer dan sumber data sekunder. Sumber data primer diperoleh secara langsung dari sumbernya dengan melakukan wawancara dengan informan utama dan informan pendukung. Informan utama dalam penelitian ini adalah santri, sedangkan informan pendukung antara lain kepala sekolah dan tenaga pengajar di lingkungan SMP Daarul Quran Jawa Tengah selain itu juga melibatkan pengasuh asrama. Sedangkan sumber data sekunder dalam penelitian ini berupa dokumen-dokumen penting yang diperlukan dalam penelitian. Teknik pengumpulan data penelitian ini dengan metode observasi, metode wawancara dan dokumentasi. Analisis data penelitian ini menggunakan pengumpulan data, reduksi data, penyajian data dan penarikan kesimpulan. Teknik analisis data tersebut dilakukan berdasarkan model analisis interaktif berikut :

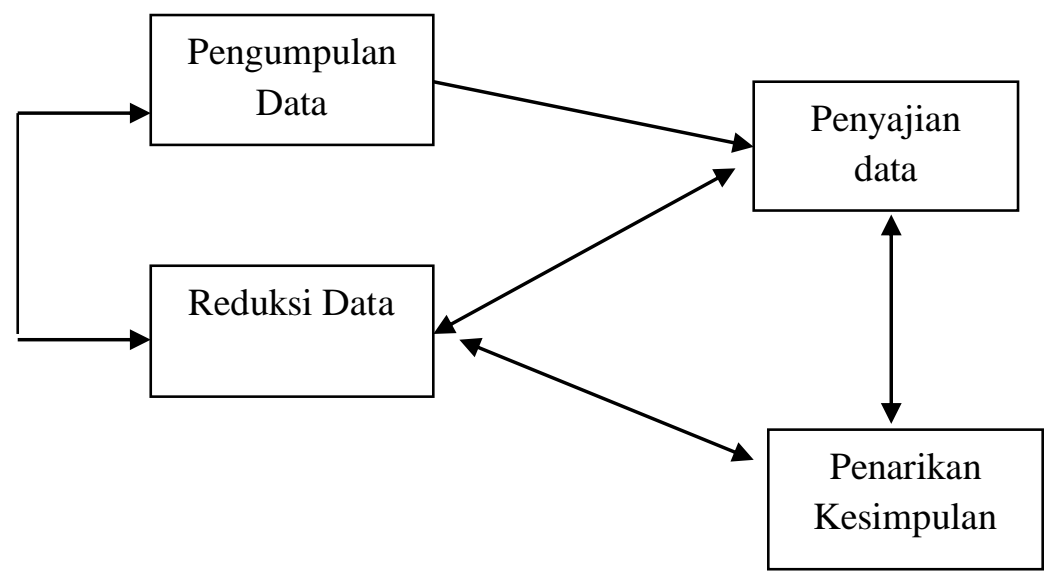

Bagan 3.2 Model Analisis Interaktif Miles dan Hubberman Sumber (Sugiyono, 2013:335)

\section{HASIL DAN PEMBAHASAN}

Komunikasi antar budaya para santri yang berbeda seringkali 
menimbulkan kesalahpahaman pada aspek pola komunikasi maupun pola budaya di lingkungan Pondok Pesantren Tahfidz Daarul Quran Jawa Tengah. Data diperoleh melalui observasi langsung ke Pondok Pesantren Tahfidz Daarul Quran Jawa Tengah dan bertemu langsung serta melakukan wawancara dengan santri, kepala sekolah, pengasuh asrama, serta tenaga pengajar di lingkungan pondok pesantren.

Deskripsi Informan Utama (Santri)

\begin{tabular}{|c|c|c|c|c|c|}
\hline No & $\begin{array}{c}\text { Nama } \\
\text { Informan }\end{array}$ & Kelas & Asal & $\begin{array}{c}\text { Lama } \\
\text { Tinggal }\end{array}$ & $\begin{array}{c}\text { Bahasa yang } \\
\text { dikuasai }\end{array}$ \\
\hline 1. & $\begin{array}{l}\text { M. Farhan } \\
\text { Zacky kelas }\end{array}$ & IX & $\begin{array}{l}\text { Kalimantan } \\
\text { Tengah }\end{array}$ & $\begin{array}{l}2,5 \\
\text { tahun }\end{array}$ & $\begin{array}{l}\text { Jawa, Indonesia, } \\
\text { Arab, Inggris dan } \\
\text { bahasa daerah } \\
\text { Kalimantan Tengah }\end{array}$ \\
\hline 2. & $\begin{array}{l}\text { Raditya } \\
\text { Faadihilah } \\
\text { Agryan } \\
\text { Nugrah }\end{array}$ & IX & Bandung & $\begin{array}{l}2,5 \\
\text { tahun }\end{array}$ & $\begin{array}{l}\text { bahasa Indonesia, } \\
\text { bahasa Sunda, } \\
\text { bahasa Betawi, } \\
\text { bahasa Arab, } \\
\text { bahasa Inggris dan } \\
\text { bahasa Jawa, }\end{array}$ \\
\hline 3. & $\begin{array}{l}\text { Andhika Fayiz } \\
\text { Halimaking }\end{array}$ & VIII & $\begin{array}{l}\text { Gresik Jawa } \\
\text { Timur }\end{array}$ & 2 tahun & $\begin{array}{l}\text { bahasa Indonesia, } \\
\text { bahasa Arab, dan } \\
\text { bahasa Jawa }\end{array}$ \\
\hline 4. & $\begin{array}{l}\text { Moch. } \\
\text { Azwansyah }\end{array}$ & IX & $\begin{array}{l}\text { Tarakan, } \\
\text { lahir di } \\
\text { Malaysia } \\
\text { keturunan }\end{array}$ & 3 tahun & $\begin{array}{l}\text { bahasa Indonesia, } \\
\text { bahasa Arab, dan } \\
\text { bahasa Inggris, } \\
\text { bahasa betawi, }\end{array}$ \\
\hline
\end{tabular}




\begin{tabular}{|c|c|c|c|c|c|}
\hline & & & $\begin{array}{l}\text { Sulawesi } \\
\text { (Bugis) }\end{array}$ & & $\begin{array}{l}\text { bahasa Jawa, } \\
\text { bahasa Bugis, }\end{array}$ \\
\hline 5. & $\begin{array}{l}\text { Nanda } \\
\text { Gustiani } \\
\text { Cahyo }\end{array}$ & VIII & $\begin{array}{l}\text { Jakarta } \\
\text { Timur } \\
\text { Rawamangun }\end{array}$ & 2 tahun & $\begin{array}{l}\text { bahasa Indonesia, } \\
\text { bahasa Arab, dan } \\
\text { bahasa Inggris, } \\
\text { bahasa betawi }\end{array}$ \\
\hline 6. & $\begin{array}{l}\text { Zufas Luthfi } \\
\text { Mahfi }\end{array}$ & VIII & Yogyakarta & $\begin{array}{l}\text { Sejak } \\
\text { lahir }\end{array}$ & $\begin{array}{l}\text { bahasa Indonesia, } \\
\text { bahasa Arab, dan } \\
\text { bahasa Jawa. }\end{array}$ \\
\hline 7. & Zikri Rahman & VIII & Jambi & 2 tahun & $\begin{array}{l}\text { bahasa Indonesia, } \\
\text { bahasa Padang, } \\
\text { bahasa Jambi, } \\
\text { bahasa Arab, dan } \\
\text { bahasa Jawa }\end{array}$ \\
\hline 8. & $\begin{array}{l}\text { Afif Tegar } \\
\text { Prayoga Utama }\end{array}$ & VIII & $\begin{array}{l}\text { Lamongan } \\
\text { Jawa Timur }\end{array}$ & $\begin{array}{l}1 \\
\text { tahun8 } \\
\text { bulan }\end{array}$ & $\begin{array}{l}\text { bahasa Indonesia, } \\
\text { bahasa Arab, dan } \\
\text { bahasa Jawa }\end{array}$ \\
\hline 9. & $\begin{array}{l}\text { Ariawan } \\
\text { Adinata }\end{array}$ & VIII & $\begin{array}{l}\text { Semarang } \\
\text { Jawa Tengah }\end{array}$ & $\begin{array}{l}\text { Sejak } \\
\text { lahir }\end{array}$ & $\begin{array}{l}\text { bahasa Indonesia, } \\
\text { bahasa Arab, dan } \\
\text { bahasa Jawa dan } \\
\text { bahasa Inggris }\end{array}$ \\
\hline 10. & $\begin{array}{l}\text { Muhammar } \\
\text { Amar Faizal }\end{array}$ & VIII & $\begin{array}{l}\text { Bangkalan, } \\
\text { Madura }\end{array}$ & $\begin{array}{l}1 \text { tahun } \\
8 \text { bulan }\end{array}$ & $\begin{array}{l}\text { bahasa Indonesia, } \\
\text { bahasa Arab, dan } \\
\text { bahasa Madura }\end{array}$ \\
\hline 11. & $\begin{array}{l}\text { Muhammad Al } \\
\text { Ghiffary } \\
\text { Sya'bana }\end{array}$ & IX & DKI Jakarta & $\begin{array}{l}2,5 \\
\text { tahun }\end{array}$ & $\begin{array}{l}\text { bahasa Indonesia, } \\
\text { bahasa Arab, dan } \\
\text { bahasa Jawa, }\end{array}$ \\
\hline
\end{tabular}




\begin{tabular}{|l|l|l|l|l|l|}
\hline 12. & $\begin{array}{l}\text { Fatih } \\
\text { Dharmawan }\end{array}$ & VIII & $\begin{array}{l}\text { Tabanan, } \\
\text { Bali }\end{array}$ & 2 tahun & $\begin{array}{l}\text { bahasa Indonesia, } \\
\text { bahasa Arab, dan } \\
\text { bahasa Bali }\end{array}$ \\
\hline
\end{tabular}

Berdasarkan hasil penelitian sebagaimana yang ditulis dalam penyajian data, ada beberapa temuan yang dapat disajikan dalam analisis data ini yaitu sebagai berikut:

1. Pola Komunikasi Antarbudaya Para Santri di Pondok Pesantren Tahfidz Daarul Quran Jawa Tengah

Pola komunikasi yang terbentuk pada santri di Pondok Pesantren Tahfidz Daarul Quran Jawa Tengah disebabkan karena adanya proses komunikasi yang setiap hari berlangsung antar sesama santri yang memiliki latar belakang kebudayaan yang berbeda. Proses komunikasi selalu dilakukan oleh para santri, karena komunikasi diperlukan untuk memenuhi kebutuhan selama di pondok pesantren serta memperkuat interaksi antar sesama santri terutama pada santri yang memiliki latar belakang kebudayaan berbeda. Proses komunikasi dilakukan oleh para santri ini secara langsung melalui proses tatap muka tanpa melalui media pendukung lain. Hal ini dilakukan agar komunikasi bisa berjalan dan efektif terutama komunikasi yang dilakukan dengan orang-orang yang berbeda kebudayaan.

Proses komunikasi yang dilakukan oleh para santri tersebut dapat ditemui melalui beberapa proses komunikasi seperti berikut:

a. Proses Adaptasi dengan Lingkungan

Proses adaptasi merupakan salah satu proses komunikasi yang dapat ditemukan para santri di Pondok Pesantren Tahfidz Daarul Quran Jawa Tengah. Dalam proses adaptasi ini terdapat proses komunikasi verbal dan komunikasi non verbal yang mereka gunakan sebagai pendukung saat melakukan komunikasi. Komunikasi verbal yang 
digunakan untuk beradaptasi dengan lingkungan ini meliputi penggunaan bahasa sebagai alat dalam berkomunikasi. Penggunaan bahasa tersebut harus bisa dipahami oleh seluruh santri di pondok pesantren, oleh karena itu hal tersebut menjadi satu hal utama yang perlu diperhatikan. Dengan menggunakan bahasa yang tepat maka proses komunikasi antarbudaya akan dapat berjalan dengan baik dan efektif. Selain bahasa Arab mereka juga menggunakan bahasa Indonesia sebagai bahasa alternatif. Bahasa Indonesia ini digunakan ketika masing-masing pihak yang berkomunikasi dapat memahami bahasa tersebut, hal ini dilakukan untuk membentuk suatu keakraban satu sama lain.

Komunikasi verbal dilakukan dengan cara menggunakan bahasa Arab yang wajib digunakan seluruh santri dan bahasa Indonesia sebagai bahasa pemersatu sedangkan komunikasi non verbal yang dilakukan adalah simbol dan lambang yang mendukung proses komunikasi yang dilakukan selain itu sikap dan perilaku saat berkomunikasi juga menunjukkan adanya proses komunikasi non verbal ini seperti sikap perhatian ketika sedang berkomunikasi dengan cara menatap mata lawan bicara serta sikap memdengarkan dengan seksama apa yang sedang dibicarakan oleh lawan bicara.

\section{b. Proses Pengulangan Informasi}

Berdasarkan hasil wawancara yang dilakukan dengan informan kedua Raditya Faadihilah Agryan Nugrah dan informan ketiga Andhika Fayiz Halimaking menunjukkan bahwa ketika berkomunikasi informan ini terkadang harus menjelaskan kembali pesan yang dimaksudkan dari komunikasi yang dilakukan dengan santri lain di pondok pesantren. Perilaku ini dilakukan karena tidak semua santri yang diajak berkomunikasi bisa langsung memahami maksud yang disampaikan 
terutama ketika komunikasi yang dilakukan dengan santri yang memiliki kebudayaan berbeda. selain itu berdasarkan hasil observasi yang dilakukan oleh peneliti juga menunjukkan hal yang sama. Ketika berkomunikasi santri ini sering mengulang pesan yang telah disampaikan karena lawan yang diajak berkomunikasi belum memahami pesan yang disampaikan, terutama ketika masing-masing pihak yang berkomunikasi memiliki kebudayaan yang berbeda dan masing-masing pihak menggunakan logat dari kebudayaan sendiri-sendiri.

c. Sikap Saling Menghormati

Berdasarkan hasil observasi ditemukan bahwa para santri menjunjung sikap saling menghormati satu sama lain terutama ketika berkomunikasi dengan santri yang berbeda kebudayaan. Hal ini tampak saat seorang santri yang lain sedang berkomunikasi maka santri yang diajak berkomunikasi tersebut mendengarkan dengan seksama serta tidak mengejek logat yang digunakan. Hal tersebut juga sebaliknya ketika seorang santri akan memberikan umpan balik (feedback) terhadap komunikasi yang sedang berlangsung, maka masing-masing pihak tidak akan saling menghina satu sama lain dan berusaha saling menghormati. Berdasarkan proses komunikasi yang telah dijabarkan diatas, selanjutnya maka dapat dianalisis bahwa pola komunikasi antarbudaya yang dilakukan oleh para santri di Pondok Pesantren Tahfidz Daarul Quran Jawa Tengah meliputi :

a) Pola Komunikasi Antarbudaya Simbolik

Dalam pola ini terbagi menjadi dua lambang yaitu verbal dan nonverbal. Lambang verbal dalam penelitian ini meliputi penggunaan bahasa yang digunakan oleh para santri ini saat melakukan komunikasi antarbudaya, sedangkan lambang nonverbal yang digunakan saat berkomunikasi adalah isyarat anggota tubuh antara 
lain mata, kepala, bibir dan tangan. Berdasarkan wawancara informan keenam, bernama Zufas Luthfi Mahfi Kelas VIII berasal dari Yogyakarta, perbedaan pola komunikasi verbal dan non verbal yang pernah terjadi di pondok pesantren adalah orang Yogyakarta ketika berbicara dengan lawan tuturnya bernada rendah, halus dan sopan serta tidak dengan mengangkat bahu, tetapi perilaku teman santrinya yang berasal dari luar Jawa ketika berbicara dengannya bernada tinggi, cepat sambil mengangkat suara dan mengangkat bahu seperti orang yang sedang marah, hal ini merupakan salah satu contoh lambang verbal dan nonverbal yang terjadi di lingkungan Pondok Pesantren Tahfidz Daarul Quran Jawa Tengah.

b) Pola Komunikasi Antarbudaya Langsung

Pola komunikasi antarbudaya langsung ini merupakan pola komunikasi yang didalamnya terdapat umpan balik (feedback) dari komunikan kepada komunikator sebagai penentu utama keberhasilan komunikasi. Dalam pola komunikasi ini proses komunikasi berjalan terus karena adanya umpan balik tersebut. Hal ini dapat ditemukan dalam proses komunikasi yang dilakukan oleh para santri di Pondok Pesantren Tahfidz Daarul Quran Jawa Tengah dengan latar belakang kebudayaan berbeda yang mana proses komunikasi ini dilakukan secara langsung melalui tatap muka selama di pondok pesantren sehingga umpan balik (feedback) bisa langsung diberikan saat berkomunikasi.

2. Faktor Pendukung Pola Komunikasi Antarbudaya Para Santri di Pondok Pesantren Tahfidz Daarul Quran Jawa Tengah

Berikut beberapa faktor yang menjadi pendukung dalam proses komunikasi antarbudaya para santri di Pondok Pesantren Tahfidz Daarul 
Quran Jawa Tengah, antara lain:

a) Kemampuan Beradaptasi

Para santri di Pondok Pesantren Tahfidz Daarul Quran Jawa Tengah mencoba untuk beradaptasi dengan suasana yang ada di pondok pesantren terutama bagi santri yang berasal dari wilayah luar pulau Jawa. Mereka harus bisa beradaptasi dengan kebudayaan tersebut agar ketika mereka berkomunikasi dengan santri lain di pondok pesantren ini bisa memahami pesan yang disampaikan sehingga tidak terjadi kesalahpahaman. Hal tersebut juga bisa dilihat dari hasil wawancara dengan informan kelima Nanda Gustiani Cahyo yang menjelaskan tentang pentingnya adaptasi dalam mendukung komunikasi antarbudaya. Menurut informasi yang didapat dari mereka adaptasi dilakukan agar lebih mudah memahami budaya di lingkungan baru sehingga mempermudah proses komunikasi antarbudaya yang akan dilakukan.

b) Kemampuan Berkomunikasi

Berdasarkan hasil wawancara dengan informan keempat Moch. Azwansyah. Para santri mencoba untuk menjelaskan secara langsung pesan yang akan disampaikan kepada teman-temannya, dengan begitu diharapkan komunikasi bisa berjalan efektif karena pesan yang ada langsung menuju ke pokok pembahasan. Selain itu dengan berusaha untuk melakukan komunikasi yang baik kepada seluruh santri yang ada di pondok pesantren maka akan terwujud komunikasi antarbudaya yang baik dan efektif serta dapat meminimalisir terjadinnya konflik antarbudaya.

c) Kejelasan Informasi

Informasi yang jelas akan mempermudah seseorang ketika menerima sebuah pesan. Terutama ketika orang tersebut memiliki kebudayaan yang berbeda dengan lawan bicaranya, pesan yang jelas akan mempermudah seseorang melakukan komunikasi dan dapat 
meminimalisir kesalahan saat berkomunikasi antara komunikator dengan komunikan. Data tentang kejelasan informasi ini dapat dilihat dari hasil wawancara dari informan ketujuh Zikri Rahman. Menurut Zikri informasi yang jelas akan membuat seseorang lebih mudah memahami komunikasi yang dilakukan, dengan begitu komunikasi akan berjalan lancar dan efektif.

d) Bahasa

Bahasa dan lambang dapat menjadi faktor pendukung sekaligus sebagai faktor pennghambat dalam melakukan komunikasi antarbudaya. Sebagai faktor pendukung dalam penelitian ini bahasa dan lambang digunakan oleh para santri di pondok pesantren dalam melakukan komunikasi baik komunikasi dengan orang-orang yang satu kebudayaan maupun dengan orang-orang yang berbeda kebudayaan. Bahasa sebagai alat untuk mempermudah mereka dalam proses komunikasi. Dengan bahasa serta lambang maka komunikasi yang dilakukan akan berjalan baik dan lancar.

e) Menjunjung Tinggi Sikap Ramah dan Sopan Santun

Berdasarkan hasil wawancara dengan informan kedelapan Afif Tegar Prayoga Utama yang mengungkapkan faktor pendukung berupa sikap ramah dan sopan santun sangat diperlukan untuk menciptakan komunikasi antarbudaya yang baik. Adapun manfaat yang bisa diambil dari adanya sikap ramah dan sopan santun ketika berkomunikasi adalah dapat membuat seseorang merasa nyaman dan senang berada di pondok pesantren ini. Hal tersebut tentu akan mempermudah dalam memahami kebudayaan yang masih terbilang baru bagi santri yang berasal dari wilayah luar Jawa. Para santri di Pondok Pesantren Tahfidz Daarul Quran Jawa Tengah tidak pernah ragu untuk saling membantu satu sama 
lain dalam memahami kebudayaan teman mereka.

f) Menghormati Perbedaan Budaya

Menghormati perbedaan budaya merupakan suatu hal yang penting dalam menjalin suatu komunikasi yang baik. Dengan adanya rasa saling menghormati pada masing-masing pihak maka proses komunikasi akan berjalan terus-menerus. Hal ini seperti yang dilakukan oleh para santri di Pondok Pesantren Tahfidz Daarul Quran Jawa Tengah, yang mana mereka mencoba untuk saling membuka diri antar sesama agar bisa saling mengenal satu sama lain sehingga dapat memahami kebudayaan masing-masing dan dapat menciptakan komunikasi yang baik. Data tentang faktor pendukung yang berkaitan sikap saling percaya ini juga dapat dilihat dari hasil wawancara dengan informan keduabelas Fatih Dharmawan. Fatih mengungkapkan dengan kepercayaan yang diberikan kepada teman-teman di pondok pesantren maka akan terwujud komunikasi antarbudaya yang lebih efektif lagi serta komunikasi yang dilakukan akan berjalan terus menerus karena adanya rasa saling percaya yang mengakibatkan timbul sikap saling terbuka satu sama lain.

g) Adanya Ketertarikan Berkomunikasi

Ketertarikan berkomunikasi dapat dilihat berdasarkan penjelasan dari informan kesebelas Muhammad Al Ghiffary Sya'bana mana dengan menciptakan suasana yang menarik saat berkomunikasi maka hal tersebut dapat membuat lawan bicara kita tertarik untuk terus melakukan komunikasi sehingga diharapkan dapat menciptakan suatu keharmonisan melalui komunikasi antarbudaya yang berkelanjutan.

3. Faktor Penghambat Pola Komunikasi Antarbudaya Para Santri di Pondok Pesantren Tahfidz Daarul Quran Jawa Tengah

Berdasarkan hasil penyajian data-data yang diperoleh dari para informan di lokasi penelitian, maka dapat dianalisis bahwa faktor 
penghambat dalam melakukan komunikasi antarbudaya yang dilakukan oleh para santri di Pondok Pesantren Tahfidz Daarul Quran Jawa Tengah yang memiliki latar belakang kebudayaan yang berbeda meliputi :

a) Karakteristik Santri

Setiap komunikasi pada umumnya dipengaruhi oleh karakteristik komunikator dan komunikan itu sendiri. Jika komunikator menunjukkan sikap keakraban maka komunikannya juga akan melakukan feedback yang serupa. Namun sebaliknya jika komunikator menunjukkan sikap yang kurang baik maka bisa saja komunikan juga memberikan respon yang kurang baik. Hal ini seperti yang terjadi pada santri yang memiliki kebudayaan Jawa, yang mana santri ini merasa bahwa anak yang memiliki kebudayaan selain Jawa seperti Madura, Batak, Papua dan lain sebagainya memiliki watak yang keras. Sehingga ketika berkomunikasi harus lebih berhati-hati agar tidak menimbulkan konflik. Apabila komunikator kurang memahami, cara komunikasi yang dipilih mungkin tidak sesuai dengan karakteristik komunikan dan hal ini dapat menghambat komunikasi karena dapat menimbulkan kesalahpahaman begitu juga sebaliknya. Analisis diatas dapat juga ditemukan berdasarkan hasil wawancara dengan informan kesepuluh Muhammar Amar Faizal yang menjelaskan tentang watak atau karakteristik teman-teman mereka di lingkungan pondok pesantren.

b) Persepsi dalam Berkomunikasi

Persepsi dalam berkomunikasi dapat dilihat berdasarkan hasil penelitian bahwa kebudayaan baru pada awalnya terlihat aneh bagi santri berkebudayaan lain sehingga membuat pelaku komunikasi merasa minder dalam melakukan komunikasi. Persepsi ini dapat diketahui berdasarkan hasil wawancara dengan informan kedua Raditya Faadihilah Agryan 
Nugrah yang mengungkapkan bagaimana persepsi itu dapat mempengaruhi sekaligus menjadi penghambat dalam melakukan komunikasi antarbudaya.

c) Perbedaan Budaya dan Bahasa

Salah satu contoh perbedaan budaya dan bahasa yaitu ketika ada santri yang menggunakan bahasa dari daerah asalnya maka santri lain yang memiliki kebudayaan berbeda tidak dapat memahami apa yang dikatakan oleh santri tersebut. Oleh karena itu faktor bahasa harus diperhatikan dengan seksama agar tidak terjadi salah penafsiran yang mengakibatkan kesalahpahaman. Data ini diperkuat dengan hasil wawancara dengan informan ketiga Andhika Fayiz Halimaking yang menjelaskan tentang pengaruh perbedaan bahasa yang dimiliki oleh masing-masing santri dapat menjadi faktor penghambat dalam melaksanakan komunikasi antarbudaya.

d) Pengaruh Budaya Lain

Berdasarkan data yang diperoleh pada penelitian ini, siswa yang memiliki kebudayaan minoritas mengikuti merasa harus selalu santri yang jumlahnya lebih banyak atau pihak mayoritas karena santri minoritas ini merasa kalau tidak mengikuti pihak mayoritas maka akan dikucilkan. Hal seperti ini harusnya tidak terjadi karena dapat menghambat proses komunikasi yang berlangsung. Hal ini juga bisa dilihat dari hasil wawancara dengan informan pertama yaitu M. Farhan Zacky kelas yang memiliki anggapan bahwa budaya minoritas harus mengikuti keputusan budaya mayoritas. Hal ini menjeaskan tentang adanya pengaruh budaya yang lebih banyak dibandingkan dengan budaya yang lebih sedikit. 


\section{SIMPULAN}

Berdasarkan hasil penelitian melalui observasi serta melakukan wawancara dengan informan utama dan pendukung, maka penelitian ini dapat disimpulkan sebagai berikut:

1. Pola Komunikasi Para Santri di Pondok Pesantren Tahfidz Daarul Quran Jawa Tengah

Pola komunikasi yang terbentuk pada santri di Pondok Pesantren Tahfidz Daarul Quran Jawa Tengah disebabkan karena adanya proses komunikasi yang setiap hari berlangsung antar sesama santri yang memiliki latar belakang kebudayaan yang berbeda. Proses komunikasi para santri meliputi proses adaptasi dengan lingkungan, proses pengulangan informasi dan sikap saling menghormati. Berdasarkan proses komunikasi terssebut pola komunikasi antarbudaya para santri di Pondok Pesantren Tahfidz Daarul Quran Jawa Tengah meliputi pola komunikasi simbolik dan langsung. Pola komunikasi simbolik terdapat terdiri atas pola komunikasi verbal berupa bahasa yang digunakan para santri di lingkungan pondok pesantren serta pola komunikasi nonverbal berupa perilaku maupun ekspresi saat berinteraksi dengan teman santri, hal itu terjadi secara langsung sehingga akan menimbulkan umpan balik (feedback) dari komunikator kepada komunikan.

2. Faktor Pendukung dan Penghambat Pola Komunikasi Antarbudaya Para Santri di Pondok Pesantren Tahfidz Daarul Quran Jawa Tengah

Faktor pendukung yang terdapat pada proses komunikasi antarbudaya yang dilakukan oleh para santri di Pondok Pesantren Tahfidz Daarul Quran Jawa Tengah ini adalah adanya ketertarikan saat berkomunikasi, kemampuan berkomunikasi, sikap saling percaya, sikap ramah dan sopan santun, kemampuan beradaptasi, kejelasan informasi, bahasa dan lambang. 
Sedangkan faktor penghambat komunikasi anntarbudaya ini adalah watak individu, persepsi pelaku komunikasi, pengaruh budaya lain, dan perbedaan bahasa.

Berdasarkan pada hasil penelitian yang telah penulis paparkan, maka terdapat beberapa saran dari penulis sebagai berikut:

1. Bagi Santri

Para santri sebaiknya mengenal keanekaragaman budaya yang ada di pondok pesantren agar mereka dapat memahami berbagai macam kebudayaan yang ada di Indonesia.

2. Bagi Pondok Pesantren

Memberikan bekal kepada para santri terkait dengan keragaman budaya yang ada di lingkungan pondok pesantren sehingga mereka dapat memahami dan beradaptasi dengan baik serta meminimalisir terjadinya kesalahpahaman pola komunikasi antar budaya di lingkungan pondok pesantren.

3. Bagi Peneliti Lain

Perlu diadakan penelitian lebih lanjut tentang pola komunikasi antarbudaya dan semoga penelitian ini dapat berguna dan dapat dijadikan bahan rujukan untuk melakukan penelitian selanjutnya pada khalayak dan sasaran lain.

\section{DAFTAR PUSTAKA}

Effendy, Onong Uchana. 2014. Dinamika Komunikasi. Bandung: Remaja Rosdakarya.

Liliweri, Alo. 2011. Dasar-Dasar Komunikasi Antarbudaya. Yogyakarta: Pustaka Pelajar.

Moleong, Lexy J. 2016. Metodologi Penelitian Kualitatif. Bandung: PT Remaja Rosdakarya.

Mulyana, Deddy. 2008. Komunikasi Efektif: Suatu Pendekatan Lintas Budaya. Bandung: PT Remaja Rosdakarya. 
Atrianing Yessi W dan Nimas P, Analisis Pola Komunikasi... (hlm.204-221)

Sugiyono. 2013. Metode Penelitian Kuantitatif, Kualitatif dan $R \& D$. Bandung: Alfabeta.

221 | http://journal.unesa.ac.id/index.php/paramasastra 